\title{
S1 - Uso del suelo como tratamiento secundario de aguas residuales domésticas
}

\author{
Wilber J. Pérez-Flores \\ Universidad Nacional Autónoma de Nicaragua, Managua, Nicaragua
}

*Autor al que se dirige la correspondencia: pwilberj@gmail.com

\section{Resumen}

- 1 propósito del estudio es evaluar la eficiencia de remoción de contaminantes de aguas residuales domésticas ¿(ARD) usando el suelo como tratamiento, para utilizarlo como una alternativa al alcance de poblaciones sin acceso a sistemas de alcantarillado y tratamiento de ARD. Se construyó un sistema piloto de tratamiento de ARD compuesto por una fosa séptica y zanjas de infiltración, el cual funciona por percolación en el subsuelo, donde el agua atraviesa una capa de piedrín y luego se percola en el suelo. El estudio se realizó en la planta experimental de tratamiento de ARD en la ciudad de Guatemala, durante octubre 2014 a mayo del 2015. Se tomaron como parámetros los indicados en el Reglamento de descargas y reúsos de las aguas residuales y la disposición de lodos. Los análisis se realizaron en el Laboratorio Unificado de Química y Microbiología Sanitaria, a excepción de los metales pesados, aceites y grasas. La evaluación del rendimiento del sistema piloto de tratamiento de ARD demostró una eficiente remoción de contaminantes, con resultados en sólidos suspendidos de $99 \%$, color 95\%, DBO5de $99 \%$, DQO de $98 \%$, fósforo de $87 \%$ y coliformes fecales de $93 \%$. Respecto al nitrógeno se eliminaron los resultados extremos, obteniéndose una eficiencia de remoción de $23 \%$. Se comprobó que el suelo es capaz de remover con eficacia la mayoría de contaminantes de las ARD a excepción del nitrógeno, el cual requiere un estudio más detallado para entender su comportamiento en el proceso.

Palabras claves: Fosa séptica, zanja de infiltración, remoción de contaminantes

\section{Abstract}

$\mathrm{T}$ The purpose of the study is to evaluate the efficiency of domestic wastewater (DW) removal of pollutants using soil as a treatment, to be used as an alternative to the population without access to sewerage systems and DW treatment. It was built a pilot system for treatment of DW, including a septic pit and infiltration ditches, which works by percolation in the subsoil, the water flows through a stone layer and then is percolated in the soil The study was carried out in the DW experimental treatment plant in Guatemala city, during October 2014 to May 2015. It were taken as parameters the indicated in the regulation of downloads and reuse of water waste and the disposal of sludge. Analysis were done in the Unified Laboratory for Chemistry and Sanitary Microbiology, with the exception of heavy metals, oils and fats. Evaluation of the DW pilot's system treatment plant showed an efficient contaminant removal, with results in solid suspended of $99 \%$, color $95 \%$, DBO5 of $99 \%$, COD of $98 \%$, phosphorus of $87 \%$ and fecal coliform of $93 \%$. Nitrogen values show elimination of extreme contents, with a removal efficacy of $23 \%$. It was found that the soil is able to effectively remove most of the contaminants from DW except for nitrogen, which requires a more detailed study to understand their behavior in the process.

Keywords: Septic pit, infiltration ditch, contaminant removal 